\title{
Learning about invertebrates, outdoors: effects of teaching program outside the school premises in Brazil
}

Ana Rute Amadeu Santana anarutesantana@yahoo.com.br 0000-0001-7084-5306 Universidade Estadual de Maringá Maringá, Paraná, Brasil.

\section{Ana Tiyomi Obara}

anatobara@gmail.com 0000-0002-2149-6477 Universidade Estadual de Maringá. Maringá, Paraná, Brasil.

\section{Jürgen Drissner}

juergen.drissner@uni-ulm.de 0000-0003-0837-6216 Universidade de UIm, UIm, Germany

\begin{abstract}
Conservation of invertebrate biodiversity is affected by misconceptions towards these small animals. Thus, studies and practices that promote a better relationship between human and nature are needed. The present study deals with learning outside the classroom, based on an Educational Program conceived by Drissner et al. (2014) applied to German students. Our goal was to access the knowledge on invertebrates of students in Brazil, through the Teaching Program. It also evaluated learning and changes in students' emotions and attitudes. The students were divided in intervention group comprised of 26 students who visited the Park; the other 30 students in control group. Attitudes of students before and after visiting the Ecological Park were accessed and compared with the control group. Students' attitudes improved after the visit even though they spent only a short time at the Ecological Park. They manifested more positive emotions towards small animals and showed more biological understanding than their peers. Results may contribute towards the practice of environmental education in Brazil and a short time outdoors may be easily integrated into the school curricula. Furthermore, it may contribute towards the construction of students' knowledge on the environment and encourage positive environmental attitudes that may forecast the environmental for future generations.
\end{abstract}

KEYWORDS: Environmental education. Invertebrate's conservation. Misconceptions. Classroom. Outside practice. 


\section{INTRODUCTION}

Environmental education has been employed to improve society's perception and awareness on the value of nature and biodiversity. Environmental education in schools is an important tool that provides children with constant dynamic, and interdisciplinary education. In fact, outdoors programs may be highlighted as an approach to learning through concrete experience for sustainability awareness (UNESCO, 2008).

The Brazilian Environmental Education Policy (PNEA Law 9795/1999) establishes that environmental educational activities provide social value, knowledge, skills, and attitudes focusing on the conservation of the environment and the preservation of the species (ALMEIDA; SOARES, 2012). Nevertheless, invertebrates have a significant role in the conservation of the environment and they may be used to stimulate conservation awareness and activities (SAMWAYS et al., 1995).

The high biodiversity of insects and other invertebrates play an important role in the functioning of ecosystems and they are crucial to maintain their diversity (BARUA et al., 2012, WILSON, 1987). Approximately $75 \%$ of living organisms on the planet are adapted to different terrestrial ecosystems (BORROR; DELONG, 1969, MC GAVIN, 2001). These small animals play important ecological roles in nutrient cycling, pollination of plants, biological control, among others (FISHER, 1998; WILSON 1987). However, humans, especially children, sometimes have aversive and negative attitudes towards invertebrates: they are seen as repugnant, repulsive, dangerous, and even worthless beings (SILVA; COSTA NETO, 2004). Many people have phobic reactions to the mere mention of such words as "mosquitoes", "spiders", "scorpions", and others (KELLERT, 1993).

It is very common for Brazilian children of different ages to inquire about the usefulness of these animals (SOUZA; SOUZA 2005). Since textbooks still qualify animals as helpful or harmful, wild or domestic (ARAÚJO et al., 2011, Santos; BONOTTO, 2011), a challenge is posed because invertebrates, albeit most are harmless, often cause feelings of disgust and fear and remind people of myths that trigger negative emotions and attitudes towards them (KELLERT, 1993). This behavior contributes towards the process of species extinction (WAGLER; WAGLER 2011).

So that negative attitudes towards invertebrates could be dealt with, outdoor activities that promote interactions between children and animals are essential, this plays a formative role for values, perceptions and knowledge in the construction of more positive attitudes (DREWS, 2002). The realization of outdoor activities, besides propagating sustainable actions, can to change the attitudes, and contribute to formation of citizens committed with the life, mainly because education is a strategic form that aims to contribute to the values formation and skills toward for sustainability (LEFF, 2012).Thus, activities focused on environmental concern, are linked to the maintenance and valorization of nature, providing critical reflections regarding the current society for the development of a more ecological awareness.

Within this perspective, an outdoor educational program may be a viable strategy in promoting positive attitudes towards natural life (DRISSNER et al., 2011, 2014, 2016), featuring more effective and pleasurable learning (LINDEMANN- 
MATTHIES, 2006). Further, contact with nature provides feelings, attitudes and sustainable behaviors that positively influence the emotions, well-being and happiness in the human being (NISBET et al., 2009). This fact enables environmental educators to make use of the benefits of nature to promote positive emotional bonds and changes in attitudes towards the environment and animals.

Educational programs outside the classroom offer several advantages: children are taught more effectively and pleasantly about animal species and biodiversity (DRISSNER et al., 2011, 2014). The fact that students encounter animals in nature makes them appreciate their habitat. Direct contact with nature helps them to increase environmental awareness, positive environmental attitudes and a caring for life (FAWCETT, 2002). Although spent time is very short, the contact with nature favors effectiveness and may be easily integrated in school curricula (DRISSNER et al., 2011, 2014, 2016).

Current study aims to identify the knowledge of primary school children from a public school in the state of Paraná, Brazil, on invertebrates, and evaluates students' learning and changes in emotions and attitudes during a half-day teaching program outside the classroom. Moreover, proposes discuss about the invertebrates conceptions between Brazilian and German students.

\section{MATERIALS AND METHODS}

Current experiment was based on the Environmental Education Program through half-day teaching outside the school (DRISSNER et al., 2014). The research was composed by 56 students, comprising 28 girls and 28 boys. Research was conducted at the Pedagogical Application School of a public university in the northern region of the state of Paraná, Brazil, used as a research laboratory for the testing and experimentation of teaching activities, pedagogical innovation and educational stages that promotes the reflection toward the environment and life.

The students were divided into two groups, or rather, 26 formed the intervention group (11 boys and 15 girls) who visited the city's Ecological Park during half a day, and 30 students formed the control group who has the traditional classroom (17 boys, 13 girls), all belonging to the same school and the same grade (Grade 7).

A semantic differential scaling (Likert scale) on invertebrates was presented to the students from both group to identify their attitudes towards small animals, such as spiders, ants, dragonflies, centipedes, beetles, and others. The children were invited to mark their attitudes on the scale between two bipolar adjectives (for instance, "Boring-Fascinating," "Disgusting-Cute" or "UnnecessaryNecessary"). The students scored 13 bipolar adjectives according to their attitudes and emotions towards the invertebrates (e. g. fear, disgust).

The students from the intervention group filled the questionnaire to identify prior attitudes and emotions of students towards invertebrates, seven days before visiting the Ecological Park, from 13:30 to 17:30 on the marked date. The control group also answered an identical questionnaire during the same period.

At the Ecological Park, the students were invited to think, reflect and discuss terrestrial invertebrates, their diversity, morphology, nutrition, behavior, habitat, 
predators, and extinction. Didactic handouts were prepared as a practical guide for better explanation.

The students were divided into small groups with 2 to 3 children each looking for and collecting invertebrates in different habitats. They were advised to handle the animals with care and respect. They were encouraged to search among the undergrowth (leaves, branches, trunks), to carefully pick up the animals with tweezers and brushes, not to hurt them, and store them provisionally in acrylic bottles. The children used cameras to record unknown animals for further research on the Internet. The animals were observed under magnifying glasses and their anatomical characteristics reported and represented by drawings, addressing the organisms in their natural habitats, adaptations to the environment, diversity of concepts, biodiversity, and richness. Discussions ensued why in one place more species were found than in others, the importance of the forest undergrowth, tree trunks as a haven for several species, their feeding relationships and their importance in the environment. After observation and analysis of the invertebrates, they were returned to the same environment in which they were found. Seven days after, both groups (intervention and control) completed the same questionnaire for the second time as a follow-up. The control group, after the research, also visited the Ecological Park for the same activities opportunities.

\section{RESULTS}

Statistica 7.0 was employed for data analysis. Wilcoxon test for paired samples was used to analyze the development of the groups (Table 1). The intervention group showed a significant difference in twelve out of the 13 bipolar adjective pairs. After the visit in the Ecological Park, the students evaluated the small animals as funnier, safer, more valuable, more necessary, better, more appealing, more precious, more fascinating, cuter, more natural, cooler, and more interesting than before. The students in the control group had changed in two ratings estimating these small animals as more necessary and more precious than before (Table 1). The study showed significant differences in gender (Tables 2 and 3). After the intervention, the boys changed their opinion on four attitudes towards small animals, considering them as more necessary, better, funny and more precious than before, while the control group at the second time also changed for one rating: small animals were more necessary than they were considered before. The girls in the intervention group showed a significant change in ten out of the 13 pairs of bipolar adjectives, rating small animals as safer, more valuable, more appealing, funnier, cuter, more interesting, more necessary, better, cooler and more precious than before. The female control group also changed one pair of adjectives, rating the small animals as more precious than before. 
Table 1 - Average pre- and post-test attitudes with regard to small animals for intervention and control groups. Statistics of significant differences were calculated by Wilcoxon non-parametric tests for paired samples.

\begin{tabular}{|c|c|c|c|c|c|c|c|c|c|}
\hline & & $\begin{array}{c}\text { In- } \\
\text { pre }\end{array}$ & $\begin{array}{c}\text { M- } \\
\text { post }\end{array}$ & $\begin{array}{c}\text { Z- } \\
\text { valu } \\
\text { e }\end{array}$ & p-level & $\begin{array}{c}\text { C- } \\
\text { pre }\end{array}$ & $\begin{array}{c}\text { M- } \\
\text { post }\end{array}$ & $\begin{array}{c}\text { Z- } \\
\text { valu } \\
\text { e }\end{array}$ & $\begin{array}{c}\text { p- } \\
\text { level }\end{array}$ \\
\hline Boring & Fascinating & 3.00 & 4.23 & 2.35 & $0.019^{*}$ & 3.37 & 3.73 & 0.89 & 0.372 \\
\hline Dangerous & Safe & 2.73 & 3.88 & 3.23 & $0.001^{* *}$ & 3.47 & 3.73 & 0.79 & 0.431 \\
\hline Useless & Valuable & 3.23 & 4.69 & 2.80 & $0.005^{* *}$ & 4.07 & 4.47 & 0.81 & 0.420 \\
\hline Disgusting & Cute & 2.64 & 3.69 & 2.07 & $0.039^{*}$ & 2.79 & 3.50 & 1.54 & 0.123 \\
\hline $\begin{array}{c}\text { Uninterestin } \\
\text { g }\end{array}$ & Interesting & 3.92 & 5.00 & 1.98 & $0.048^{*}$ & 4.47 & 4.77 & 0.73 & 0.465 \\
\hline $\begin{array}{c}\text { Unnecessar } \\
\text { y }\end{array}$ & Necessary & 4.04 & 5.77 & 3.45 & $0.001^{* *}$ & 4.10 & 4.77 & 2.09 & $\begin{array}{c}0.037 \\
*\end{array}$ \\
\hline Bad & Good & 3.38 & 5.12 & 3.33 & $0.001^{* *}$ & 3.70 & 4.30 & 1.31 & 0.191 \\
\hline Morbid & Natural & 4.69 & 5.92 & 2.38 & $0.017^{*}$ & 6.17 & 6.33 & 0.43 & 0.666 \\
\hline Repulsive & Appealing & 2.85 & 4.35 & 3.13 & $0.002^{* *}$ & 2.80 & 3.53 & 1.80 & 0.072 \\
\hline Uncool & Cool & 3.73 & 4.85 & 2.27 & $0.023^{*}$ & 4.21 & 4.53 & 0.44 & 0.658 \\
\hline Dull & Funny & 2.54 & 4.50 & 3.72 & $0.000^{* * *}$ & 3.23 & 3.90 & 1.44 & 0.150 \\
\hline Weird & Harmless & 3.58 & 4.35 & 1.18 & 0.236 & 3.83 & 4.13 & 0.69 & 0.493 \\
\hline Worthless & Precious & 4.73 & 6.42 & 3.21 & $0.001^{* *}$ & 4.93 & 5.93 & 2.17 & $\begin{array}{c}0.030 \\
*\end{array}$ \\
\hline
\end{tabular}

${ }^{*} p<0.05 ; * * p<0.01 ; * * * p<0.001$

Table 2: Average pre- and post-test attitudes with regard to small animals for intervention and control groups (males). Statistics of significant differences were calculated by Wilcoxon non-parametric tests for paired samples

\begin{tabular}{|c|c|c|c|c|c|c|c|c|c|}
\hline \multicolumn{7}{|c|}{ Intervention Group: boys (N=11) } & \multicolumn{3}{|c|}{ Control Group: boys (N=17) } \\
\hline pre & & $\begin{array}{c}M \\
\text { post }\end{array}$ & $\begin{array}{c}\text { Z- } \\
\text { value }\end{array}$ & p-level & $\begin{array}{c}M \\
\text { pre }\end{array}$ & $\begin{array}{c}M \\
\text { post }\end{array}$ & $\begin{array}{c}\text { Z- } \\
\text { value }\end{array}$ & $\begin{array}{c}\boldsymbol{p} \text { - } \\
\text { level }\end{array}$ \\
\hline Boring & Fascinating & 3.27 & 4.45 & 1.60 & 0.110 & 3.18 & 3.53 & 0.47 & $\begin{array}{c}0.63 \\
6\end{array}$ \\
\hline Dangerous & Safe & 2.91 & 3.64 & 1.78 & 0.074 & 2.94 & 3.24 & 0.63 & $\begin{array}{c}0.53 \\
0\end{array}$ \\
\hline Useless & Valuable & 2.91 & 3.73 & 0.61 & 0.541 & 4.29 & 4.71 & 0.56 & $\begin{array}{c}0.57 \\
6\end{array}$ \\
\hline $\begin{array}{c}\text { Disgusting } \\
\text { Cute }\end{array}$ & 3.82 & 4.27 & 0.30 & 0.767 & 2.81 & 3.29 & 0.70 & $\begin{array}{c}0.48 \\
5\end{array}$ \\
\hline $\begin{array}{c}\text { Uninteresti } \\
\text { ng }\end{array}$ & Interesting & 4.82 & 4.82 & 0.21 & 0.834 & 4.29 & 4.47 & 0.10 & $\begin{array}{c}0.91 \\
7\end{array}$ \\
\hline $\begin{array}{c}\text { Unnecessa } \\
\text { ry }\end{array}$ & Necessary & 3.36 & 5.00 & 2.19 & $0.028^{*}$ & 3.82 & 4.59 & 2.04 & $\begin{array}{c}0.04 \\
1 *\end{array}$ \\
\hline Bad & Good & 3.27 & 4.91 & 2.24 & $0.025^{*}$ & 3.12 & 4.06 & 1.53 & $\begin{array}{c}0.12 \\
5\end{array}$ \\
\hline Morbid & Natural & 4.27 & 5.91 & 1.89 & 0.059 & 5.94 & 6.53 & 1.15 & $\begin{array}{c}0.24 \\
9\end{array}$ \\
\hline Repulsive & Appealing & 3.09 & 3.91 & 1.33 & 0.183 & 2.47 & 3.41 & 1.68 & $\begin{array}{c}0.09 \\
4\end{array}$ \\
\hline Uncool & Cool & 3.91 & 4.45 & 0.71 & 0.476 & 4.00 & 4.35 & 0.31 & $\begin{array}{c}0.76 \\
0\end{array}$ \\
\hline Dull & Funny & 2.82 & 4.64 & 2.24 & $0.025^{*}$ & 3.00 & 3.53 & 0.94 & $\begin{array}{c}0.34 \\
7\end{array}$ \\
\hline
\end{tabular}




\begin{tabular}{|c|c|c|c|c|c|c|c|c|c|}
\hline Weird & Harmless & 4.00 & 4.45 & 0.46 & 0.646 & 3.47 & 4.06 & 1.13 & $\begin{array}{c}0.25 \\
8\end{array}$ \\
\hline Worthless & Precious & 4.55 & 6.45 & 2.52 & $0.012 *$ & 4.88 & 5.76 & 1.20 & $\begin{array}{c}0.23 \\
0\end{array}$ \\
\hline
\end{tabular}

Table 3: Average for pre- and post-test attitudes with regard to small animals for intervention and control groups (females). Statistics of significant differences were calculated by Wilcoxon non-parametric tests for paired samples.

\begin{tabular}{|c|c|c|c|c|c|c|c|c|c|}
\hline \multicolumn{6}{|c|}{ Intervention Group: Girls ( $\mathbf{N = 1 5 )}$} & \multicolumn{4}{|c|}{ Control Group: Girls ( $N=13$ ) } \\
\hline & & $\begin{array}{c}M \\
\text { pre }\end{array}$ & $\begin{array}{c}M \\
\text { post }\end{array}$ & $\begin{array}{c}\mathrm{Z}- \\
\text { value }\end{array}$ & $p$-level & $\begin{array}{c}M \\
\text { pre }\end{array}$ & $\begin{array}{c}M \\
\text { post }\end{array}$ & $\begin{array}{c}\mathrm{Z}- \\
\text { value }\end{array}$ & $\begin{array}{c}p- \\
\text { level }\end{array}$ \\
\hline Boring & Fascinating & 2.80 & 4.07 & 1.82 & 0.069 & 3.62 & 4.00 & 0.71 & 0.477 \\
\hline Dangerous & Safe & 2.60 & 4.07 & 2.79 & $0.005^{* *}$ & 4.15 & 4.38 & 0.39 & 0.695 \\
\hline Useless & Valuable & 3.47 & 5.40 & 2.83 & $0.005^{* *}$ & 3.75 & 4.15 & 0.66 & 0.508 \\
\hline Disgusting & Cute & 1.71 & 3.27 & 2.55 & $0.011^{*}$ & 2.77 & 3.77 & 1.42 & 0.155 \\
\hline $\begin{array}{c}\text { Uninteresti } \\
\text { ng }\end{array}$ & Interesting & 3.27 & 5.13 & 2.34 & 0.019* & 4.69 & 5.15 & 1.19 & 0.234 \\
\hline $\begin{array}{c}\text { Unnecessar } \\
y\end{array}$ & Necessary & 4.53 & 6.33 & 2.54 & $0.011 *$ & 4.46 & 5.00 & 0.83 & 0.407 \\
\hline Bad & Good & 3.47 & 5.27 & 2.45 & $0.014^{*}$ & 4.46 & 4.62 & 0.21 & 0.834 \\
\hline Morbid & Natural & 5.00 & 5.93 & 1.48 & 0.139 & 6.50 & 6.08 & 0.63 & 0.529 \\
\hline Repulsive & Appealing & 2.67 & 4.67 & 2.84 & $0.005^{* *}$ & 3.23 & 3.69 & 0.71 & 0.477 \\
\hline Uncool & Cool & 3.60 & 5.13 & 2.45 & $0.014 *$ & 4.46 & 4.77 & 0.53 & 0.594 \\
\hline Dull & Funny & 2.33 & 4.40 & 3.06 & $0.002 * *$ & 3.54 & 4.38 & 1.08 & 0.279 \\
\hline Weird & Harmless & 3.27 & 4.27 & 1.02 & 0.308 & 4.31 & 4.23 & 0.36 & 0.721 \\
\hline Worthless & Precious & 4.87 & 6.40 & 2.20 & $0.028 *$ & 5.00 & 6.15 & 2.52 & $\begin{array}{c}0.012 \\
*\end{array}$ \\
\hline
\end{tabular}

\section{DISCUSSION}

Our main findings indicate that the students who participated in environmental education through a half-day outdoor teaching program showed significant changes in their emotions and attitudes toward small animals. Results inform on the importance of outdoor educational programs, valorized as a tool for environmental education and ecology teaching (WÜNSCHMANN et al., 2016, DRISSNER et al., 2008, 2011, 2014, LINDEMANN-MATTHIES, 2006).

The educational program described in current analysis favored highly positive changes with regard to invertebrates by the children and corroborated studies by Drissner et al. $(2008,2011,2014)$ with children in half-day teaching school programs in the "Green Classroom" of the Botanical Garden of the University of Ulm, Germany. The authors discovered that children who attended the "Green Classroom" exhibited fewer misconceptions, more knowledge and positive emotions towards small animals. A comparative analysis between current study and investigation by Drissner et al. (2014) revealed that, among the significant changes, students in Brazil and Germany differed in four of the 13 pairs of bipolar adjectives. Brazilians students chose safe, natural, appealing and funny attributes, whereas German children described the animals harmless. In no instance Brazilian students marked the small animal harmless, showing that Brazilian students live in a different reality than their peers in Germany. 
In tropical countries, certain insects such as gnats, mosquitoes, bugs and other invertebrates are associated with the transmission of diseases addressed in the school curriculum. Some animals such as spiders and scorpions may be poisonous or cause fear and are seen as dangerous. They may be usually found in gardens, backyards and in houses under construction. Children are normally warned by parents and teachers to avoid them. This is due to accidents involving these animals which are a public health problem in Brazil, with an average of approximately 5,000 cases with spiders and 8,000 with scorpions per year (BOCHNER; STRUCHINER, 2003). Traditions rooted in Brazilian culture coupled to a high number of accidents affect children's interaction with these animals (MOURA et al., 2010) and could be the reason for several misconceptions and myths causing negative attitudes towards invertebrates.

The above result is interesting since Brazilian children changed their attitudes but maintained their fear. In fact, they scored adjectives that they would admire the animals from a distance, without touching them (safe, natural, appealing and funny), which is different from harmless. This means that the animals may be touched to know whether they are really inoffensive. German children understand that almost all invertebrates are harmless and are really beneficial. They know that they are normally docile and not aggressive. In fact, the outdoor program is important in Brazil so that students may understand that it is crucial to safeguard these animals, despite fear. Studies conducted by Drissner et al. (2016) in Costa Rica, also a tropical country, showed that invertebrates are considered dangerous, probably for the same reasons as in Brazil. The authors highlighted that the students' attitudes in Costa Rica rated invertebrates as more precious, an adjective also noted by Brazilian students.

The group of Brazilian boys had the same number of significant changes when compared to those in German boys: four changes of classification attitudes were found. After the intervention, boys from Germany and Brazil agreed in one case, or rather, that invertebrates were rated better than before.

German girls showed more changes than their male peers, similar to what occurred in Brazil. According to Drissner et al. (2014), they changed six out of the 13 pairs of adjectives, whereas in current study ten out of the 13 adjective pairs were changed. Among the adjectives in common between the two studies, one must underscore that small animals were classified as more valuable, interesting and necessary, better and more precious than before. Overall, the girls gained more detailed knowledge than boys, as highlighted in other studies (BRAUN et al., 2010, DRISSNER et al., 2014). The literature shows that, among the typical gender patterns, girls perform better in the field of biological sciences, as evidenced in some studies (PROKOP et al., 2007, JONES et al., 2000).

Current study indicate that studying invertebrates through educational program outside the classroom increases feelings and information with regard to these animals since they enhance learning on concepts, ecology, species identification, behavior, habitat and food relationships, among others. Studies on invertebrates improve feelings and respect for animals and the environment since they are crucial to ecosystems. Unfortunately, currently many species are endangered and viewed with disgust, misconceptions and negative attitudes (WAGLER; WAGLER 2011, WILSON, 1987). Such negative behavior disrupts environmental education (BIXLER et al., 1999) for sustainability. 
Current study suggests that positive changes in knowledge occur through an educational program involving small animals in environmental studies, even though changes in attitudes are very difficult to prove (DRISSNER et al., 2008, 2014). According to LaHart (1978), attitudes towards living beings depend on feelings and beliefs that people build throughout their lives. The author argues that feelings and beliefs are important elements for the development of knowledge and decision-making. They may influence the way individuals evaluate the outside world. According to Winkel (1995), the emotional relationships with animals promote environmental ethics and knowledge and are inspired by feelings emanating from the heart.

The educational program under discussion is not merely interesting but enhances the changing of attitudes outside the classroom for longer periods. However, Drissner et al (2014) remark that German school teachers find it very difficult to find longer time periods for educational issues outside the classroom. However, the authors considered relevant the short educational program since students' positive changes on small animals were evidenced. They also highlighted that they may be easily integrated into the school curriculum. This result may also contribute towards environmental education in Brazil, where a strategy may be adopted in which children acquire experiences. Experiences mean a lot more than words and involve biodiversity, plants, animals and their habitats, or rather, a reorientation of educational practices with regard to sustainability (GADOTTI, 2010). Although environmental education should be approached in a multidisciplinary and interdisciplinary way, the Brazilian curriculum is rather inflexible and makes it difficult to practice the environmental dimension out of the classroom for a long period. Consequently, an environmental education program which requires a shorter period outside the classroom could be integrated more easily to the Brazilian school curriculum.

The outdoor activities practices have shown that it is possible to work environmentally in a playful way in contact with nature. This moment allows students to discuss and carry out in practice what is not approached within the traditional classroom. Activities outside the classroom can promote critical reflection, change of attitude, and the formation of new values in this relationship society and nature. In addition, the role of outdoor classes as a tool to promote one environmental education with the formation of critical citizens, with socioenvironmental responsibility, environmental, students prepared for the transformation of reality and to face of environmental problems are highlighted. It will surely contribute towards the construction of students' knowledge on the natural environment and encourage positive environmental attitudes that may foreground the environmental performance of future generations. 


\title{
Aprendendo sobre invertebrados, ao ar livre: efeito de um programa de ensino fora da sala de aula no Brasil
}

\begin{abstract}
RESUMO
A conservação da biodiversidade de invertebrados é afetada por equívocos e atitudes negativas em relação a esses pequenos animais. Assim, são necessários estudos e práticas que promovam uma melhor relação entre o ser humano e a natureza. O presente estudo foi sobre um programa de aprendizagem fora da sala de aula, como um programa educacional, com base nos estudos de Drissner et al. (2014) realizados com estudantes alemães, e que tem contribuído para a prática da educação ambiental nas escolas da Alemanha. O estudo leva em consideração a aprendizagem por meio da experiência ao ar livre, que busca identificar conhecimento biológico dos alunos e desenvolver atitudes positivas em relação aos animais. Assim, o presente estudo teve como objetivos identificar o conhecimento dos alunos em uma escola pública no Brasil sobre os invertebrados; avaliar a aprendizagem; e as mudanças nas emoções e atitudes dos alunos. Os estudantes foram divididos em dois grupos, 26 formaram o grupo de intervenção, que visitou o Parque Ecológico da cidade, e 30 alunos serviram como grupo controle, todos pertencentes à mesma escola e ao mesmo ano (grau 7). Foram avaliadas as atitudes dos alunos em relação aos invertebrados, antes e depois de terem visitado o Parque Ecológico, e as respostas foram analisadas em relação ao grupo controle. Embora os estudantes tenham passado um tempo curto no Parque Ecológico, suas concepções e atitudes melhoraram significativamente após a visita. Os alunos demonstraram emoções mais positivas em relação aos pequenos animais e uma compreensão mais biológica, do que aqueles que não frequentaram o parque, e que tiveram apenas aulas em sala. Este resultado pode contribuir para a prática de educação ambiental também no Brasil, já que este programa demanda pouco tempo fora da sala de aula, o que pode ser facilmente integrado no currículo escolar. Além disso, contribui para a construção do conhecimento dos alunos sobre o ambiente natural e incentiva atitudes ambientais positivas que podem refletir na qualidade ambiental das futuras gerações.
\end{abstract}

PALAVRAS-CHAVE: Educação ambiental. Conservação de invertebrados. Concepções. Sala de aula. Prática ao ar livre. 


\section{Acknowledgement}

Santana, Ana Rute Amadeu and Obara, Ana Tiyomi thanks to CAPES-PNPD for the Post-Doctoral financial support.

\section{REFERENCES}

ALMEIDA, T.F.; SOARES M.A. Ações em educação ambiental na prevenção de acidentes com animais perigosos na zona oeste do Rio de Janeiro. Educação Ambiental em Ação. n. 41. 2012.

ARAÚJO, O. L., A. L.; COSTA, R. R. COSTA; J. H. NICOLELI. "Uma abordagem diferenciada da aprendizagem de Sistemática filogenética e taxonomia zoológica no Ensino Médio". In: Congresso Nacional de Educação - Educere: I Seminário Internacional de Representações Sociais, Subjetividade e Educação: Curitiba. 2011.

BARUA M., D. J. GURDAK, R. A. AHMED, AND J. TAMULY. 2012. Selecting flagships for invertebrate conservation. Biodiversity Conservation 21: 1457-1476.

BIXLER, R. D., M. F. FLOYD, AND F. MYRON. Hands on or hands off? Disgust sensitivity and preference for Environmental Education activities. Journal Environmental Education 30: 4-11. 1999.

BOCHNER, R.; STRUCHINER, C.J. Epidemiologia dos acidentes ofídicos nos últimos 100 anos no Brasil: uma revisão. Caderno de Saúde Pública (Fiocruz), Rio de janeiro 19: 7-16, 2003.

BORROR, D. J.; DELONG D. M. Introdução ao estudo dos insetos. São Paulo: Edgard Blücher. 1969.

BRAUN M., R. BUYER, AND C. RANDLER. Cognitive and emotional evaluation of two outdoor programs dealing with non-native bird species. International Journal Environment \& Science Ed 5: 151-168, 2010.

DREWS C. Knowledge and wild animals as pets in Costa Rica. Anthrozoös 15: 119 138, 2002.

DRISSNER, J. R.; HAASE, H-M; WITTIG, S.; HILLE, K. Short-term environmental education: long-term effectiveness? Journal of Biology Education, 48: 1, 2014. 
DRISSNER, J.; HILLE K.; S. DEBATIN, AND H-M. HAASE. Das Grüne Klassenzimmer im Botanischen Garten der Universität UIm - eine Wirkungsanalyse. Diskurs Kindheits- und Jugendforschung, 2: 209-18, 2008.

DRISSNER, J.; SIMONTE, M.; HILLE, K. Attitudes of School Children in Germany and Costa Rica towards Invertebrates - A Comparison. Research Journal Education, 2: 34-37, 2016.

FAWCETT, L. Children's wild animal stories: questioning inter-species bonds. Canadian Journal Environmental Education, 7: 125-39, 2002.

FISHER, B. L. Insect behavior and ecology in conservation: preserving functional species interactions. Annals Entomolological Society of America, 9: 155-158, 1998.

GADOTTI, M. "Escola Cidadã - Questões da Nossa Época". In: Escola Cidadã. São Paulo: Cortez Editora, 2010.

JONES M. G.; HOWE, A.; RUA, M. J. Gender differences in students' experiences, interests, and attitudes toward science and scientists. Science Education, 84: 180 $-192,2000$.

KELLERT, S. R. Values and perceptions of invertebrates. Conservation Biology, 7(4): 845-55, 1993.

LaHART, D. E. The influence of knowledge on young people's perceptions about wildlife. Florida State University: College of Education, 1978.

LEFF, E. Saber ambiental: sustentabilidade, racionalidade, complexidade, poder. 9 Ed. Petrópolis (RJ): Vozes, 2012, 494p.

LINDEMANN-MATTHIES, P. Investigating nature on the way to school: Responses to an educational programme by teachers and their pupils. International Journal of Science Education, 28: 895-912, 2006.

MC GAVIN, G.C. Essential Entomology: An Order By Order Introduction. Oxford: University Press. 2001

MOURA, M. R.; COSTA, H. C.; SÃO-PEDRO, V. A.; FERNANDES, V. D.; FEIO, R. N. O relacionamento entre pessoas e serpentes no leste de Minas Gerais, sudeste do 
NISBET E. K. L.; ZELENSKI, J. M.; MURPHY, S. A. The nature relatedness scale: linking individuals' connection with nature to environmental concern and behavior. Environmental Behavior, 41: 715-740, 2009.

POLÍTICA NACIONAL DE EDUCAÇÃO AMBIENTAL, Lei 9795. 27 April 1999. Diário Oficial da República Federativa do Brasil, Brasília. Disponível em: www.planalto.gov.br/ccivil_03/Leis/L9795.html. Acesso em: 23/05/2016.

PROKOP, P.; TUNCER, G.; CHUDÁ, J. Slovakian Students' Attitudes toward Biology. Eurasia Journal of Mathematics, Science \& Technology, Ed 3: 287-295. 2007.

SAMWAYS, M. J.; STORK, N. E.; CRACRAFT, J.; EELEY, H. A. C.; FOSTER, M.; LUND, G.; HILTON-TAYLOR, C. "Scales, planning and approaches to inventorying and monitoring". Pp. 517-475. In: Heywood V.H., and R.T. Watson (Eds). Global biodiversity assessment. United Nations Environment Programme, Cambridge: Cambridge University Press. 1995.

SANTOS, J. R.; BONOTTO, D. M. B. "Educação ambiental e animais não humanos: linguagens e valores atribuídos por professoras do ensino fundamental". In: VI encontro de pesquisa em educação ambiental. Anais do VI Epea: Ribeirão Preto, 2011.

SILVA, T. F. P.; COSTA NETO, E. M. Percepção de insetos por moradores da comunidade de Olhos d'Água, município de Cabaceiras do Paraguaçu, Bahia, Brasil. Boletin Sociedad Entomologica Aragoneza, 35: 261-268, 2004.

SOUZA, C. E. P.; SOUZA, J. G. "(Re) Conhecendo os animais peçonhentos: Diferentes abordagens para a compreensão da dimensão histórica, sócio-ambiental e cultural das ciências da natureza". In: V Encontro Nacional de Pesquisa em educação em ciências. Atas do V ENPEC. Bauru: ABRAPEC, 2005.

UNESCO. The contribution of early childhood education to a sustainable society. Paris, 2008.

WAGLER, R.; WAGLER, A. "Arthropods: Attitude and incorporation in preservice elementary teachers". International Journal Envieornment \& Science Education, 6 (3): 229-250, 2011.

WILSON, E. Little things that run the world. Conservation Biology, 1 (4): 344-46, 1987. 
WINKEL, G. Umwelt und Bildung: Denk- und Praxisanregungen für eine ganzheitliche Natur- und Umwelterziehung. Kallmeyersche Verlagsbuchhandlung: Seelze, 1995.

WÜNSCHMANN, S.; WÜST-ACKERMANN P., RANDLER C.; VOLLMER, C.; GREULICH, $\mathrm{H}$. Learning Achievement and Motivation in an Out-of-School Settin-Visiting Amphibians and Reptiles in a Zoo Is More Effective than a Lesson at School. Research Science Education, 1-22, 2016.

Recebido: 2017-04-20

Aprovado: 2017-08-08

DOI: 10.3895/rbect.v11n1.5819

Como citar: SANTANA, A. R. A.; OBARA, A. T.; DRISSNER, J. Learning about invertebrates, outdoors: effects of a forum outside the school premises in Brazil. Revista Brasileira de Ensino de Ciência e Tecnologia, v. 11, n. 1, 2018. Disponível em: <https://periodicos.utfpr.edu.br/rbect/article/view/5819>. Acesso em: xxx.

Correspondência: Ana Rute Amadeu Santana - anarutesantana@yahoo.com.br Direito autoral: Este artigo está licenciado sob os termos da Licença Creative Commons-Atribuição 4.0 Internacional.

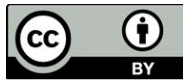

